\title{
Assessment and prevention of acute health effects of weather conditions in Europe, the PHEWE project: background, objectives, design
}

Paola Michelozzi*1, Ursula Kirchmayer ${ }^{1}$, Klea Katsouyanni², Annibale Biggeri ${ }^{3}$, Glenn McGregor ${ }^{4}$, Bettina Menne ${ }^{5}$, Pavlos Kassomenos ${ }^{6}$, Hugh Ross Anderson 7 , Michela Baccini ${ }^{3}$, Gabriele Accetta ${ }^{1}$, Antonis Analytis ${ }^{2}$ and Tom Kosatsky 5

Address: ${ }^{1}$ Department of Epidemiology Local Health Authority Roma E, Rome, Italy, ${ }^{2}$ Department of Hygiene \& Epidemiology, University of Athens Medical School, Athens, Greece, ${ }^{3}$ Department of Statistics, University of Florence, Florence, Italy, ${ }^{4}$ Department of Geography, King's College London, London, UK, 5 WHO, Regional Office for Europe, Rome, Italy, ${ }^{6}$ Department of Astrogeophysics, University of Joannina, Joannina, Greece and ${ }^{7}$ Division of Community Health Sciences, St. George's, University of London, UK

Email: Paola Michelozzi* - michelozzi@asplazio.it; Ursula Kirchmayer - kirchmayer@asplazio.it; Klea Katsouyanni - kkatsoug@cc.uoa.gr; Annibale Biggeri - abiggeri@ds.unifi.it; Glenn McGregor - glenn.mcgregor@kcl.ac.uk; Bettina Menne - bme@ecr.euro.who.int; Pavlos Kassomenos - pkassom@uoi.gr; Hugh Ross Anderson - r.anderson@sghms.ac.uk; Michela Baccini - baccini@ds.unifi.it; Gabriele Accetta - g.accetta@cspo.it; Antonis Analytis - aanalit@med.uoa.gr; Tom Kosatsky - tkosatsk@santepub-mtl.qc.ca

* Corresponding author

Published: 24 April 2007

Environmental Health 2007, 6:12 doi:10.1186/1476-069X-6-12
Received: 25 September 2006

Accepted: 24 April 2007

This article is available from: http://www.ehjournal.net/content/6/I//2

(c) 2007 Michelozzi et al; licensee BioMed Central Ltd.

This is an Open Access article distributed under the terms of the Creative Commons Attribution License (http://creativecommons.org/licenses/by/2.0), which permits unrestricted use, distribution, and reproduction in any medium, provided the original work is properly cited.

\begin{abstract}
Background: The project "Assessment and prevention of acute health effects of weather conditions in Europe" (PHEWE) had the aim of assessing the association between weather conditions and acute health effects, during both warm and cold seasons in 16 European cities with widely differing climatic conditions and to provide information for public health policies.
\end{abstract}

Methods: The PHEWE project was a three-year pan-European collaboration between epidemiologists, meteorologists and experts in public health. Meteorological, air pollution and mortality data from 16 cities and hospital admission data from 12 cities were available from 1990 to 2000 . The short-term effect on mortality/ morbidity was evaluated through city-specific and pooled time series analysis. The interaction between weather and air pollutants was evaluated and health impact assessments were performed to quantify the effect on the different populations. A heat/health watch warning system to predict oppressive weather conditions and alert the population was developed in a subgroup of cities and information on existing prevention policies and of adaptive strategies was gathered.

Results: Main results were presented in a symposium at the conference of the International Society of Environmental Epidemiology in Paris on September 6 $^{\text {th }} \mathbf{2 0 0 6}$ and will be published as scientific articles. The present article introduces the project and includes a description of the database and the framework of the applied methodology.

Conclusion: The PHEWE project offers the opportunity to investigate the relationship between temperature and mortality in 16 European cities, representing a wide range of climatic, socio-demographic and cultural characteristics; the use of a standardized methodology allows for direct comparison between cities. 


\section{Background}

Interest in the impact of weather on human health is increasing, especially in the light of potential climate changes. The rapid increase of greenhouse gases in the atmosphere is expected to increase both mean temperature and temperature variability around the world [1,2]. Climatologists project that, in temperate climates, a 2$3{ }^{\circ} \mathrm{C}$ increase in average summer temperatures will double the frequency of periods characterized by extremely high temperatures [3]. Such changes would be characterized by the increased frequency and intensity of heat waves and cold spells, and could lead to an increase in heat related illness episodes and deaths.

The association between high and low temperatures and mortality has been investigated in several studies. Most investigations have focused on the effect of temperature on health through a time series approaches or focusing on extreme events (heat waves, cold spells) using episode analysis.

A review of the epidemiological studies on the effect of high temperatures on mortality conducted after 1970 identified sensitive groups among the elderly, persons with pre-existing cardiovascular and respiratory diseases and/or those of low socioeconomic status [4]. The heat effect appears within few days of exposure and some harvesting is observed $[4,5]$. The heterogeneity of the impact of heat on health reflects geographical, climatic and cultural variability, as well as different capacities to adapt to extreme temperatures and needs to be addressed more in depth in a large scale study [4-7]. Recently, studies on the effect of high temperatures on morbidity provided evidence of an increase in emergency hospital admissions for specific causes in young children and subjects over 75 years of age, though with a smaller effect for admissions than for mortality [8]. Schwartz et al. reported an effect of heat on cause-specific admissions within a few days after exposure and a short-term displacement of the events (harvesting effect) [9].

With regards to the effects of cold, several studies have suggested that there is a considerable burden in terms of mortality, especially in the elderly and in persons affected by chronic respiratory or cardiovascular diseases $[5,7,10$ $12]$. This effect is generally more prolonged than for heatrelated deaths [10-13] and, in contrast with evidence during heat waves, extreme cold seems not to be followed by any mortality displacement [13]. The impact on morbidity usually anticipates death as suggested by the biological mechanisms underlying cold-related illnesses [14]. However, the influence of cold on outcomes other than mortality has, to date, received little investigation. The few studies present have focused on cardiovascular admis- sions and results showed an association with low temperatures [9].

In the 1990s, the APHEA (Air Pollution and Health: an European Approach) project investigated the short-term effects of air pollution on health throughout Europe [15]. In the time series analysis performed for this project, temperature was considered an important confounder of the association between air pollution and mortality [16].

The project "Assessment and Prevention of Acute Health Effects and Weather Conditions in Europe" (PHEWE) was initiated in 2002, with the general aim of assessing the association between weather and acute health effects (daily mortality and hospital admissions) in Europe and to provide information for public health policy on preventive and adaptive actions. The specific objectives of the project were:

- to create a European database of meteorological variables and health indicators;

- to perform time series analysis using a standardized methodology and evaluate the short term health effects of weather conditions on daily mortality and daily hospital admissions, both during warm and cold seasons;

- to investigate the role of air pollution as a potential effect-modifier using a standardized methodology;

- to define a synoptic weather classification system in different European areas, and to evaluate synoptic categories associated with increased mortality and morbidity;

- to experiment the use of Heat/health watch warning systems (HHWWS) to predict in advance high risk weather conditions;

- to produce a health impact assessments of weather conditions on mortality;

- to define public health actions aimed at the prevention of adverse health effects of weather in Europe.

\section{Methods \\ The database}

Data was collected for 16 European cities, representing a large spectrum of climatic conditions: Athens, Barcelona, Budapest, Krakow, Dublin, Helsinki, Ljubljana, London, Milan, Paris, Prague, Rome, Stockholm, Turin, Valencia, and Zurich, including about 30 million European citizens (Table 1). The number of city residents ranges between 6,8 million (London) to 260.000 (Ljubljana), with the percentage of the elderly population (over 75 years) between 5\% (Helsinki) and 10\% (Barcelona). The gender and age- 
adjusted mortality rate is highest in Budapest (1093.6) and lowest in Milan (439.4).

\section{Health data}

Mortality data were provided from 16 cities and hospital admission data from 12 cities for all available years in the period 1990-2000 (Table 1), all referring to the city residents and to events that occurred in the city, except for Dublin, where hospital admissions referred also to nonresidents. Taking into account the results of previous studies $[10,12,17]$ and the biological plausibility of the health effects $[7,14,18,19]$, the following causes of death and hospital admissions were selected for all ages combined and specific age groups (0-14 yrs, 15-64 yrs, 65-74 yrs, 75+ yrs): all causes (excluding external causes), ICD-9: 1799; cardiovascular diseases, ICD-9: 390-459; cerebrovascular diseases, ICD-9: 430-438; respiratory diseases, ICD9: 460-519.

Data from cold and warm seasons were analyzed separately, defining summer as the months from April to September and winter as the months between October and March.

Table 2 gives an overview of the mean daily number of deaths by cause and season. Data on cerebrovascular mortality were not available in three cities (Athens, Paris, Zurich). For all other causes the mean daily counts were lower in the summer season.

Emergency hospital admission records for the same causes (plus influenza, ICD-9: 487) were selected, following the
APHEA-2 project protocol [15]. Only main causes of admission were considered. In table 3 mean daily admission counts are summarized by cause and season. Two cities could not provide all requested causes, namely Paris and Zurich. Generally, admission counts were higher in the cold season, especially for respiratory diseases.

\section{Meteorological variables}

For each city, data were retrieved from a weather station located in the city centre as well as from the nearest airport weather station for the entire study period. The following meteorological variables, recorded every three hours, were collected: air temperature, dew point temperature, wind speed, wind direction, sea level pressure, total cloud cover, solar radiation, precipitation, visibility. Quality control included a descriptive overview of the variables in all cities, detecting possible errors and extreme values, testing for homogeneity and correcting erroneous values where possible.

Table 4 gives an overview of the daily mean values observed in the participating cities. Mean summer temperatures ranged between $12.0^{\circ} \mathrm{C}$ in Helsinki and $23.5^{\circ} \mathrm{C}$ in Athens, in Valencia the lowest inner-city temperature range was reported. Relative humidity levels were highest in Dublin (81\%) and lowest in Athens (57\%). In winter, the lowest temperature was observed in Helsinki $\left(-0.9^{\circ} \mathrm{C}\right)$ and the highest in Valencia $\left(13.7^{\circ} \mathrm{C}\right)$, which is also the city with lowest relative humidity $(69 \%)$ and the smallest temperature range. In the last column of the table, the values for maximum apparent temperature (see exposure assessment) are included. For Barcelona, 3-hourly meteor-

Table I: PHEWE cities: characteristics and data series available

\begin{tabular}{|c|c|c|c|c|c|}
\hline \multirow[b]{2}{*}{ City } & \multicolumn{3}{|c|}{ Characteristics } & \multicolumn{2}{|c|}{ Health data - Time series used } \\
\hline & Population & $\% 75+$ & Mortaliy rate $(\times 100.000) *$ & Mortality & Hospital Admissions \\
\hline Athens & 3188305 & 6.4 & 663.6 & $1992-1996$ & \\
\hline Barcelona & $|5| 297 \mid$ & 10.1 & 542.5 & $1992-2000$ & $1994-1997$ \\
\hline Budapest & I 797222 & 7.3 & 1093.6 & $|992-200|$ & $1997-2000$ \\
\hline Dublin & 481854 & 5.3 & 826.7 & $1990-2000$ & $|994-200|$ \\
\hline Helsinki & $955 \quad 143$ & 5.0 & 590.0 & $1990-2000$ & \\
\hline Krakow & 741510 & $8.9 * *$ & 805.4 & $1990-1996$ & \\
\hline Ljubljana & 263290 & 5.9 & 719.1 & $1992-1999$ & 1997-1999 \\
\hline London & 6796900 & 6.8 & 584.5 & $1992-2000$ & $1992-2000$ \\
\hline Milan & I 304942 & 9.5 & 439.4 & $1990-2000$ & $1990-1999$ \\
\hline Paris & 6161393 & 6.1 & 554.0 & $199 \mid-1998$ & $1991-1995$ \\
\hline Prague & 1183900 & 7.0 & 779.4 & $1992-2000$ & \\
\hline Rome & 2812573 & 7.3 & 497.4 & $1992-2000$ & $1998-2000$ \\
\hline Stockholm & I 173183 & 8.5 & 576.2 & $1990-2000$ & $1990-2000$ \\
\hline Turin & 901010 & 9.2 & 479.5 & $1991-1999$ & $1995-1999$ \\
\hline Valencia & 739004 & 7.6 & 595.6 & $1995-2000$ & $1996-2000$ \\
\hline Zurich & 990000 & n.a. & n.a. & $1990-1996$ & $1990-1996$ \\
\hline
\end{tabular}

$*$ adjusted for gender and age

*** $>=70$ years 
Table 2: Mortality data: daily mean and standard deviation (sd) by cause and season.

\begin{tabular}{|c|c|c|c|c|c|c|c|c|c|c|c|c|c|c|c|c|}
\hline & \multicolumn{4}{|c|}{ Total mortality (ICD-IX < 800.0) } & \multicolumn{4}{|c|}{ Cardiovascular (ICD-IX: 390-459) } & \multicolumn{4}{|c|}{ Cerebrovascular (ICD-IX: 430-438) } & \multicolumn{4}{|c|}{ Respiratory (ICD-IX:460-519) } \\
\hline & \multicolumn{2}{|c|}{ Summer* } & \multicolumn{2}{|c|}{ Winter** } & \multicolumn{2}{|c|}{ Summer* } & \multicolumn{2}{|c|}{ Winter*** } & \multicolumn{2}{|c|}{ Summer* } & \multicolumn{2}{|c|}{ Winter** } & \multicolumn{2}{|c|}{ Summer* } & \multicolumn{2}{|c|}{ Winter** } \\
\hline & mean & sd & mean & sd & mean & sd & mean & sd & mean & sd & mean & sd & mean & sd & mean & sd \\
\hline Athens & 67.46 & 10.79 & 78.26 & 13.18 & 32.62 & 7.58 & 39.46 & 8.4 & - & - & - & - & 4.19 & 2.21 & 5.08 & 2.57 \\
\hline Barcelona & 35.89 & 6.58 & 42.75 & 9.17 & 12.96 & 3.96 & 16.58 & 5.11 & 3.61 & 2.01 & 4.45 & 2.07 & 3.08 & 1.88 & 4.71 & 3.07 \\
\hline Budapest & 70.99 & 11.01 & 79.82 & 13.38 & 34.89 & 7.32 & 40.9 & 8.92 & 70.97 & 11 & 79.8 & 13.36 & 2.22 & 1.6 & 3.12 & 2.24 \\
\hline Dublin & 11.42 & 3.45 & 13.62 & 4.12 & 4.91 & 2.19 & 5.98 & 2.57 & 0.99 & 1.01 & 1.23 & I.I & 11.42 & 1.25 & 2.12 & 1.68 \\
\hline Helsinki & 17.05 & 4.18 & 18.45 & 4.6 & 8.23 & 2.96 & 8.81 & 3.1 & 2.42 & 1.56 & 2.66 & 1.65 & 1.37 & 1.18 & 1.79 & 1.47 \\
\hline Ljubljana & 6.29 & 2.58 & 7.06 & 2.89 & 2.55 & 1.63 & 3.03 & 1.84 & 0.63 & 0.8 & 0.73 & 0.86 & 0.36 & 0.62 & 0.53 & 0.75 \\
\hline London & 149.01 & 16.45 & 179.23 & 29.35 & 60.96 & 10.51 & 73.5 & 13.62 & 14.14 & 4.2 & 16.91 & 4.71 & 23.73 & 6 & 36.58 & 15.79 \\
\hline Milan & 26.3 & 5.87 & 31.86 & 7.17 & 9.85 & 3.41 & 13.21 & 4.22 & 2.88 & 1.78 & 3.58 & 1.97 & 1.65 & 1.38 & 2.54 & 1.93 \\
\hline Paris & 115.69 & 13.84 & 128.17 & 16.44 & 34.81 & 6.57 & 40.01 & 7.91 & - & - & - & - & 7.69 & 3.06 & 10.33 & 4.15 \\
\hline Prague & 34.94 & 6.51 & 38.52 & 7.49 & 20.27 & 4.87 & 22.66 & 5.62 & 5.64 & 2.62 & 6.19 & 2.72 & 1.12 & 1.09 & 1.53 & 1.32 \\
\hline Rome & 52.81 & 9.55 & 61.71 & 10.48 & 20.92 & 5.52 & 26.62 & 6.46 & 4.87 & 2.36 & 5.79 & 2.6 & 2.58 & 1.72 & 3.73 & 2.52 \\
\hline Stockholm & 27.85 & 5.41 & 30.81 & 6.3 & 13.47 & 3.84 & 14.93 & 4.28 & 2.96 & 1.72 & 3.34 & 1.81 & 2.15 & 1.5 & 2.76 & 1.88 \\
\hline Turin & 19.14 & 4.65 & 23.18 & 5.35 & 7.91 & 3.01 & 10.3 & 3.49 & 2.71 & 1.67 & 3.34 & 1.9 & 1.02 & 1.04 & 1.62 & 1.44 \\
\hline Valencia & 14.64 & 4.11 & 17.92 & 5.27 & 5.28 & 2.41 & 6.97 & 2.94 & 1.57 & 1.27 & 1.91 & 1.46 & 1.37 & 1.2 & 2.09 & 1.76 \\
\hline Zurich & 11.63 & 3.52 & 13.53 & 3.84 & 5.24 & 2.36 & 6.31 & 2.59 & - & - & - & - & 0.6 & 0.79 & 1.01 & 1.09 \\
\hline
\end{tabular}

note: * April-September, ** October-March

ological data were not available; hence maximum apparent temperature could not be calculated and mean apparent temperature was used instead. As expected, the reported values are lower than those of other cities with similar climatic conditions (Valencia, Athens, Rome).

\section{Exposure assessment}

Previous studies have used a variety of exposure measures, including maximum, minimum or average temperature, apparent temperature, humidity and dew point temperature but to date there is no standard indicator of heat or cold stress [5,13,20-22]. In the present study, maximum apparent temperature (Tappmax) was chosen as the expo-

sure variable, which is an index of thermal discomfort based on air temperature and dew point temperature [23]. Tappmax is defined as the highest value of the 3-hourly apparent temperature values, using the following formula:

$$
\mathrm{AT}=-2.653+0.994 \mathrm{Temp}+0.0153(\mathrm{Dew})^{2}
$$

where AT is apparent temperature, Temp is the air temperature in ${ }^{\circ} \mathrm{C}$ and Dew is the dew point temperature in ${ }^{\circ} \mathrm{C}$ $[24,25]$.

Table 3: Hospital admission data: daily mean and standard deviation (sd) by cause and season.

\begin{tabular}{|c|c|c|c|c|c|c|c|c|c|c|c|c|}
\hline \multirow{3}{*}{ City } & \multicolumn{4}{|c|}{ Cardiovascular (ICD-IX: 390-459) } & \multicolumn{4}{|c|}{ Cerebrovascular (ICD-IX: 430-438) } & \multicolumn{4}{|c|}{ Respiratory (ICD-IX:460-5/9) } \\
\hline & \multicolumn{2}{|c|}{ Summer* } & \multicolumn{2}{|c|}{ Winter** } & \multicolumn{2}{|c|}{ Summer* } & \multicolumn{2}{|c|}{ Winter** } & \multicolumn{2}{|c|}{ Summer* } & \multicolumn{2}{|c|}{ Winter** } \\
\hline & mean & sd & mean & sd & mean & sd & mean & sd & mean & sd & mean & sd \\
\hline Barcelona & 21.8 & 6.0 & 25.9 & 6.3 & 5.0 & 2.3 & 5.6 & 2.4 & 15.9 & 5.3 & 23.5 & 7.6 \\
\hline Budapest & 110.8 & 50.1 & 119.1 & 50.0 & 14.5 & 7.5 & 15.2 & 7.6 & 25.7 & 10.0 & 37.0 & 15.3 \\
\hline Dublin & 25.9 & 6.4 & 27.3 & 6.7 & 5.1 & 2.4 & 5.5 & 2.4 & 22.6 & 5.7 & 30.3 & 10.4 \\
\hline Ljubljana & 11.2 & 4.9 & 12.4 & 5.4 & 1.5 & 1.2 & 1.6 & 1.3 & 6.7 & 4.4 & 8.2 & 4.6 \\
\hline London & 163.8 & 31.8 & 171.2 & 34.7 & 28.3 & 6.8 & 30.0 & 7.5 & 125.2 & 25.3 & 178.6 & 52.7 \\
\hline Milan & 71.2 & 26.3 & 81.6 & 24.7 & 14.0 & 5.1 & 15.2 & 4.9 & 25.6 & 10.4 & 34.4 & II.I \\
\hline Paris & 126.5 & 45.3 & 146.5 & 44.3 & n.a. & n.a. & n.a. & n.a. & 59.0 & 19.4 & 85.0 & 22.7 \\
\hline Rome & 120.3 & 27.0 & 133.6 & 26.1 & 25.1 & 6.1 & 26.7 & 6.0 & 43.1 & 11.4 & 63.2 & 18.3 \\
\hline Stockholm & 48.0 & 12.1 & 50.8 & 12.2 & 10.4 & 3.6 & 10.9 & 3.7 & 18.3 & 6.1 & 24.2 & 7.9 \\
\hline Turin & 25.2 & 6.4 & 28.5 & 6.8 & 7.2 & 2.8 & 7.7 & 2.9 & 10.1 & 4.0 & 15.9 & 6.4 \\
\hline Valencia & 12.4 & 4.1 & 13.6 & 4.6 & 3.1 & 1.8 & 3.2 & 1.9 & 9.2 & 3.6 & 14.4 & 5.6 \\
\hline Zurich & 8.2 & 3.4 & 9.1 & 4.9 & n.a. & n.a. & n.a. & n.a. & n.a. & n.a. & n.a. & n.a. \\
\hline
\end{tabular}

* April-September, ${ }^{* *}$ October-March 
Table 4: Meteorological data: daily mean values (mean, minimum and maximum)

\begin{tabular}{|c|c|c|c|c|c|c|c|c|c|c|c|c|c|c|c|}
\hline \multicolumn{16}{|c|}{ Summer period (April-September) } \\
\hline \multirow[b]{2}{*}{ CITY } & \multicolumn{3}{|c|}{ temperature $\left({ }^{\circ} \mathrm{C}\right)$} & \multicolumn{3}{|c|}{ relative humidity (\%) } & \multicolumn{3}{|c|}{ sea level pressure $(\mathrm{hPa})$} & \multicolumn{3}{|c|}{ wind speed $(\mathrm{m} / \mathrm{s})$} & \multicolumn{3}{|c|}{ max apparent temperature $\left({ }^{\circ} \mathrm{C}\right)$} \\
\hline & mean & $\min$ & $\max$ & mean & $\min$ & $\max$ & mean & $\min$ & $\max$ & mean & $\min$ & $\max$ & mean & $\min$ & $\max$ \\
\hline Athens & 23.5 & 7.6 & 34.3 & 57 & 23 & 89 & 1013.0 & 945.8 & 1031.3 & 3.3 & 0.3 & 11.6 & 27.9 & 7.9 & 41.6 \\
\hline Barcelona & 21.7 & 8.6 & 34.2 & 66 & 29 & 99 & 1015.2 & 993.7 & 1030.6 & 6.7 & 0.9 & 22.3 & $23.3 *$ & $6.5^{*}$ & $36.9 *$ \\
\hline Budapest & 18.2 & 1.5 & 29.8 & 61 & 30 & 97 & 1014.5 & 992.6 & 1033.6 & 2.6 & 0.7 & 8.8 & 21.9 & 0.2 & 38.8 \\
\hline Dublin & 12.5 & 1.4 & 21.0 & 81 & 53 & 100 & 1014.8 & 974.7 & 1038.5 & 4.7 & I.I & 12.0 & 14.7 & 1.5 & 28.5 \\
\hline Helsinki & 12.0 & -6.5 & 25.4 & 71 & 28 & 98 & 1012.7 & 982.9 & 1035.6 & 3.6 & 0.9 & 9.6 & 14.3 & -3.7 & 32.8 \\
\hline Krakow & 15.0 & -1.6 & 26.6 & 77 & 45 & 98 & 1015.7 & 991.1 & 1033.1 & 2.3 & 0.0 & 10.1 & 19.1 & -2.3 & 35.8 \\
\hline Ljubljana & 15.9 & 0.6 & 26.5 & 75 & 33 & 98 & 970.8 & 949.2 & 985.4 & 1.6 & 0.2 & 7.0 & 20.1 & -1.7 & 35.4 \\
\hline London & 15.1 & 3.2 & 28.0 & 71 & 42 & 96 & 1015.5 & 984.1 & 1036.3 & 3.4 & 0.7 & 9.3 & 18.1 & 1.5 & 35.2 \\
\hline Milan & 20.0 & 2.5 & 29.4 & 72 & 26 & 100 & 1014.2 & 991.5 & 1031.9 & 1.7 & 0.0 & 9.4 & 25.4 & 2.7 & 40.8 \\
\hline Paris & 16.1 & 2.1 & 30.2 & 72 & 32 & 100 & 1015.9 & 988.1 & 1032.9 & 4.0 & 1.0 & 11.9 & 19.7 & 1.5 & 39.4 \\
\hline Prague & 15.1 & -1.7 & 28.7 & 70 & 31 & 98 & 972.5 & 947.0 & 990.4 & 3.8 & 0.3 & 12.0 & 17.8 & -3.3 & 36.3 \\
\hline Rome & 20.5 & 6.1 & 30.3 & 72 & 25 & 94 & 1014.2 & 992.6 & 1031.8 & 3.1 & 0.5 & 12.5 & 26.1 & 5.9 & 40.5 \\
\hline Stockholm & 12.8 & -3.2 & 26.6 & 72 & 36 & 99 & 1012.9 & 985.6 & 1036.1 & 3.3 & 0.6 & 8.1 & 15.4 & -2.1 & 34.0 \\
\hline Turin & 18.5 & 3.0 & 27.9 & 74 & 32 & 97 & 1014.2 & 993.0 & 1032.0 & 1.4 & 0.0 & 7.7 & 23.4 & 4.2 & 45.8 \\
\hline Valencia & 22.3 & 10.5 & 30.0 & 66 & 32 & 92 & 1015.1 & 995.1 & 1030.9 & 3.3 & 1.1 & 9.9 & 29.5 & 10.6 & 44.9 \\
\hline Zurich & 15.1 & 1.4 & 26.2 & 73 & 42 & 97 & 1016.4 & 993.2 & 1034.6 & 2.1 & 0.2 & 6.0 & 19.0 & 0.7 & 35.2 \\
\hline \multicolumn{16}{|c|}{ Winter period (October-March) } \\
\hline & \multicolumn{3}{|c|}{ temperature $\left({ }^{\circ} \mathrm{C}\right)$} & \multicolumn{3}{|c|}{ relative humidity (\%) } & \multicolumn{3}{|c|}{ sea level pressure $(\mathrm{hPa})$} & \multicolumn{3}{|c|}{ wind speed $(\mathrm{m} / \mathrm{s})$} & \multicolumn{3}{|c|}{ max apparent temperature $\left({ }^{\circ} \mathrm{C}\right.$} \\
\hline CITY & mean & $\min$ & $\max$ & mean & $\min$ & $\max$ & mean & $\min$ & $\max$ & mean & $\min$ & $\max$ & mean & $\min$ & $\max$ \\
\hline Athens & 13.1 & 0.7 & 26.5 & 70 & 35 & 92 & 1018.2 & 988.9 & 1035.7 & 3.2 & 0.0 & 12.8 & 14.8 & 0.8 & 34.1 \\
\hline Barcelona & 13.4 & 1.9 & 25.2 & 69 & 37 & 100 & 1018.3 & 990.2 & 1038.2 & 7.0 & 0.0 & 22.1 & $12.3^{*}$ & $0.2^{*}$ & $27.9 *$ \\
\hline Budapest & 4.0 & -12.1 & 19.5 & 77 & 36 & 100 & 1019.7 & 988.9 & 1045.7 & 2.6 & 0.5 & 8.6 & 5.0 & -9.7 & 25.7 \\
\hline Dublin & 7.0 & -4.2 & 17.8 & 85 & 54 & 100 & 1012.2 & 971.1 & 1046.3 & 6.0 & 0.6 & 17.5 & 7.5 & -4.6 & 19.8 \\
\hline Helsinki & -0.9 & -24.1 & 14.7 & 85 & 44 & 99 & 1010.8 & 949.5 & 1054.4 & 4.1 & 0.1 & 11.5 & -0.7 & -14.5 & 14.8 \\
\hline Krakow & 2.3 & -21.4 & 17.9 & 86 & 53 & 100 & 1019.2 & 987.7 & 1046.9 & 2.8 & 0.0 & 11.5 & 3.3 & -14.4 & 25.4 \\
\hline Ljubljana & 3.0 & -13.3 & 18.4 & 83 & 26 & 100 & 973.5 & 939.8 & 995.5 & 1.3 & 0.0 & 8.0 & 4.4 & -9.9 & 24.3 \\
\hline London & 7.5 & -5.2 & 18.9 & 81 & 52 & 100 & 1016.1 & 978.6 & 1044.3 & 3.7 & 0.4 & 12.5 & 8.4 & -5.6 & 24.5 \\
\hline Milan & 7.1 & -6.5 & 22.7 & 81 & 20 & 100 & 1019.1 & 986.8 & 1041.0 & 1.3 & 0.0 & 9.4 & 8.8 & -6.3 & 32.6 \\
\hline Paris & 6.9 & -10.7 & 20.0 & 84 & 37 & 100 & 1018.1 & 983.3 & 1044.8 & 4.8 & 0.5 & 14.6 & 7.7 & -9.2 & 25.4 \\
\hline Prague & 2.5 & -19.7 & 19.0 & 84 & 42 & 100 & 973.8 & 974.5 & 996.8 & 4.6 & 0.0 & 16.3 & 2.6 & -13.4 & 22.5 \\
\hline Rome & 10.5 & -2.0 & 25.8 & 80 & 34 & 98 & 1017.1 & 990.4 & 1039.1 & 3.2 & 0.3 & 13.1 & 13.5 & -1.0 & 41.5 \\
\hline Stockholm & 1.3 & -16.7 & 15.8 & 85 & 44 & 99 & 1010.9 & 947.9 & 1049.1 & 3.7 & 0.3 & 10.3 & 1.3 & -12.9 & 19.4 \\
\hline Turin & 6.0 & -6.9 & 20.2 & 76 & 25 & 99 & 1019.5 & 989.2 & 1041.4 & I.I & 0.0 & 9.5 & 8.1 & -5.9 & 29.5 \\
\hline Valencia & 13.7 & 3.4 & 26.0 & 69 & 29 & 98 & 1018.7 & 993.5 & 1034.8 & 3.1 & 0.3 & 12.2 & 18.1 & 3.2 & 35.9 \\
\hline Zurich & 4.0 & -11.7 & 17.0 & 82 & 44 & 98 & 1020.7 & 987.2 & 1044.6 & 2.4 & 0.5 & 10.3 & 4.8 & -9.2 & 23.5 \\
\hline
\end{tabular}

* for Barcelona the mean apparent temperature is reported

\section{Air pollution data}

The data collected within the APHEA-2 project were updated and integrated according the project's procedures [15]. The following pollutant measurements were recorded at each monitoring station (maximum 6): $\mathrm{SO}_{2}$ (mean 24-hours), TSP or Black Smoke (mean 24hours), PM10- if available-(mean 24-hours), $\mathrm{NO}_{2}$ (maximum 1 hour, mean 24-hours), $\mathrm{O}_{3}$ (maximum 1 hour, maximum 8-hours moving average) CO (maximum 8hour moving average).

The selection of the monitors was based on local criteria, mainly on the completeness of measurements and repre- sentation of population exposure. A standardized procedure was used to fill-in days with missing data [15].

\section{Other variables}

Through a complementary questionnaire information on other confounders and potential effect modifiers was gathered from each city, such as holidays and unusual events during the study period (e.g. health services or transportation strikes, floods, earthquakes), percentage of households with air conditioning facilities and annual restrictions on home heating use. Questions regarding the cities' population, and details concerning data quality were also included, which were useful in order to charac- 
terize the different city populations (Table 1 ) and necessary to complete the Health Impact Assessment.

\section{City-specific analysis}

For the city-specific analyses a Generalized Equation Estimation (GEE) approach was proposed as an extension of Generalized Linear Models to analyze longitudinal data, as the observations on different subjects (clusters) can be assumed independent and the observations on the same subject correlated [26].

For each city, there was an outcome variable (number of deaths or hospital admissions) and several covariates (confounders, apparent temperature, other meteorological variables), observed on different days. A marginal Poisson distribution of the dependent variable and correlation between observations during one summer/winter were assumed, while observations from different summer/winter periods were considered independent.

An exploratory analysis was carried out in order to identify the appropriate dependence structure for each season to be used in the GEE, and was similar to the approach described in Chiogna and Gaetan $[27,28]$. This approach is based on dynamic regression models, combined with a genetic algorithm for the semi-automatic selection of the best model over a large model space, covering different specifications of the correlation structure within clusters and different specifications of the systematic components of the model. The model space included models with lagged values of apparent temperature, sea level pressure (up to lag 20), and an air pollutant (up to lag 5). For the error term, up to an ARMA $(2,2)$ structure was specified. The idea was to highlight the common features across cities, in order to identify the most appropriate and common correlation structure within each season. The results of the exploratory analysis suggested to use a first order autocorrelation structure both for mortality and hospital admissions.

The common model applied to single city analysis took into account potential confounding effects of holidays, day of the week, seasonality and long-term time trend, barometric pressure, wind speed and air pollution levels, all modeled in parametric terms. An indicator of influenza epidemics was included in the model for cold season analyses (except for respiratory causes) [29]. Models for hospital admission analysis in the warm season included the moving average of total admission counts (ICD 9: <800) to offset population reduction during the summer holidays.

\section{Exposure modeling}

Based on the results of previous studies, the maximum apparent temperature of current and previous 3 days (lag
0-3) for the warm season and lag 0-15 for the cold season was chosen as the indicator of exposure; the delayed effect of the exposure was further investigated by distributed lag models in a sensitivity analysis [13].

The shape of the exposure-response curve between apparent temperature and log mortality/hospital admission rate was investigated, with a flexible approach, introducing a cubic regression spline for apparent temperature into the model.

For mortality, during the warm season a "turning point" or "threshold" was identified. The effect of high temperatures on summer mortality was also investigated focusing on the slope above the city-specific threshold of the exposure-response curve. City-specific thresholds were obtained a priori by a maximum likelihood approach, treating the apparent temperature corresponding to the minimum of the exposure-response curve as an unknown parameter [30].

For hospital admissions the effect of high temperatures in summer was investigated using a dummy variable for maximum apparent temperatures above the $90^{\text {th }}$ percentile.

The delayed effect of exposure on health outcomes was investigated using constrained and unconstrained distributed-lag models that simultaneously included variables for the same day and up to 5, 10, 15, 20, 25, 30 and (for hospital admissions) 40 days.

The impact of high temperatures on mortality was investigated through a health risk assessment analyses.

\section{Pooled analysis}

In the second stage, the city-specific effect estimates were combined to obtain pooled estimates. Overall exposureresponse curves were obtained through a fixed effect meta-analytical approach using the pooled data set and through a second stage meta-analytical approach [31], while the city-specific effect estimates and the city-specific curves for distributed-lag and time-varying effects were pooled by a hierarchical Bayesian modelling approach.

To reduce heterogeneity, pooled results were obtained grouping the cities, according to an a priori defined meteorological and geographical criteria, distinguishing between Mediterranean cities and North-Continental cities.

Second stage models including potential effect modifiers as covariates were applied in order to explore heterogeneity. Such effect modifiers included variables on the climate, the health of the population, and on air pollution 
levels and the correlation between air pollution concentrations and the meteorological variables.

\section{Confounding and synergistic effect of meteorological and air pollution variables}

Based on the models defined in the city-specific and pooled analysis, further exploration of the confounding effects of air pollutants was carried out. Possible effect modification of the impact of temperature on mortality by air pollutant levels was investigated using meta-regression models.

\section{Discussion}

While previous studies focused on single cities, the present project investigated the health impact of weather on a large scale through a variety of climatic conditions and of socio-economic and demographic characteristics, applying the same methodology, thus allowing for comparison between cities and the pooling of results.

Previous studies showed that the temperature level corresponding to the minimum mortality level varies from city to city and across different latitudes according to the local climate and probably reflecting adaptation by the local population to the temperature range in both the hot and cold season $[11,12,22,32-35]$. The analysis of the heterogeneity of the effect in European areas was accounted for in the present project, describing city-specific "change points" of the dose-response relationship and the specific shape of the dose-response curves. In the pooled analysis, heterogeneity was reduced grouping the cities according to $a$ priori geographical and meteorological characteristics.

Few studies have examined the effect of heat on outcomes other than mortality. In Chicago, during the July 1995 heat wave an $11 \%$ increase in hospital admissions was observed, with $35 \%$ of the increase among patients over 65 years [36]. More recently, studies performed in London and 12 US cities reported an increase of admissions for specific causes in the elderly and evidence of a harvesting effect $[8,9]$. To date, the present study is the largest one to investigate weather and hospital admissions in Europe.

In the present study, the role of meteorological variables other than temperature was investigated, assuming that they may contribute to the negative health effects. Therefore, an exposure indicator including dew point temperature was chosen for the time series analysis $[23,25]$, and the excess mortality/morbidity associated with specific air masses was explored using a climatologic classification based on synoptic indexes [37-39]. The choice of maximum apparent temperature as the exposure variable for the time series analysis was driven by the fact that it comprises temperature and dew point temperature in a single parameter. The simplified formula for this indicator was considered the most suitable one on the basis of data availability and quality. Several other indexes of thermal discomfort have been proposed in meteorological literature [40-43]. Among these, apparent temperature has been used as exposure measure in recent studies assessing the heat effect $[20,25,44-48]$. The importance of using heat stress indicators that combine temperature and a measure of humidity is due to the fact that on hot days the degree of humidity influences the body's ability to cool itself by evaporation and perspiration. From a modeling point of view, given that apparent temperature is obtained as linear combination of temperature and square dew point temperature, there is a strong correspondence between a regression model where a linear term for apparent temperature is included and a model where a linear term for air temperature plus a quadratic term for dew point temperature are introduced. Therefore, the percent variation in mortality/morbidity associated to $1^{\circ} \mathrm{C}$ increase in apparent temperature is expected to be similar to that of a model adjusting for dew point temperature.

When comparing the results between cities it is important to consider that the use of mean apparent temperature for Barcelona led to lower threshold values and an underestimation of the effect. Furthermore, regarding the pooled estimates, the combination of results obtained using different exposure indicators increases heterogeneity and the risk of bias in the meta-analytic estimates, in particular when thresholds or exposure-response curves are combined. Therefore, sensitivity analyses was performed excluding Barcelona from the meta-analysis and no significant differences were found.

This project focused on time series rather than on heat wave episodes, using an approach, that has been successfully used in the analyses of the effects of air pollution. Such methods have the advantage that the population under study serves as its own control, and covariates that vary between subjects, but not over time, are not potential confounders $[49,50]$.

Most time series studies performed so far showed an immediate effect of heat on mortality, with the maximum impact within two or three days (lag 0-3) [5,10-13,34], while for the cold season, an effect of up to fifteen days has been observed $[10,12,13]$. Knowledge on the lag time between exposure to extreme weather conditions and negative health outcomes is important for the development and planning of prevention plans by public health authorities and health care providers.

Evidence that the increase in mortality is followed by a deficit that, partly compensates the negative effect (harvesting) is contradictory [51]. In the present study the het- 
erogeneity of mortality/morbidity displacement patterns between cities was systematically investigated.

There is much disagreement in literature concerning human acclimatization to changing weather $[37,52,53]$. While the issue was examined by comparing the threshold temperature in different geographic locations, the possibility of a short-term acclimatization was also evaluated by comparing the dose-response function in the first period of the summer with the effects modeled in the later part of the season. This allowed also for comparison of the impact of the first heat wave in one summer with the following ones.

Given the small number of events (mortality and admissions), a unique definition of winter and summer season was chosen in order to reach a reasonable statistical power, and sensitivity analysis was performed, focusing on the three central summer months (June-August).

The relationship between increase in air pollution levels and acute health effects has been well described in the USA and in Europe [50,16]. The levels of some of the pollutants associated with increase in mortality and hospital admissions are higher during the summer period in many European areas. A synergistic effect of warm temperature and air pollution on mortality has been suggested from time series analysis conducted in Athens, whereas no effect modification detected in a study in Philadelphia, USA $[54,55]$. The present study investigated the independent effect of meteorological variables of that of ambient air pollution, and explored whether there is synergy between the two factors.

The results of the mortality analysis were also used for the development of experimental Heat/Health Watch Warning Systems (HHWWS) in five cities (Rome, Barcelona, London, Paris, Budapest). An air-mass-based climatologic index was developed, applying a synoptic approach. Using meteorological forecast data, these models are able to predict the arrival of an oppressive air mass 72 hours in advance. Such warning systems have been successfully implemented in the United States [38], whereas in Europe before the 2003 heat-wave, only in Rome a HHWWS was experimented and implemented. Therefore, the pilot study in five PHEWE cities represents an important innovation in the field of heat health prevention. The development of a standardized protocol allows for knowledge and technology transfer to other European cities in the future.

The usefulness of early warning systems is closely linked to public health strategies aiming at the prevention of negative health effects of heat. In the present project an overview of existing prevention programs in the participating cities was obtained through a questionnaire. Moreover, physiological and behavioral adaptation measures, experiences with different HHWWS, urban planning, housing standards, and socio-economic determinants of vulnerability were summarized in a comprehensive literature review. The quantification of the effect of heat/air masses exposures in the different populations was addressed through a health impact assessment (years-of-life-lost approach). These results will contribute to policy development, public health decision-making, and will be an important input for cost-benefit analysis and risk communication. Guidelines for preventive strategies and health care actions taken to lessen morbidity and mortality effects can then be based on evidences arising from this project, namely the literature review, the investigation of the state-of-the-art in the participating cities (feasibility), and the identification of susceptible populations.

\section{Conclusion}

The PHEWE project offers the opportunity to investigate the relationship between temperature and mortality in 16 European cities, representing a wide range of climatic, socio-demographic and cultural characteristics; the use of a standardized methodology allows for direct comparison between cities. The analysis of the effect of weather on hospital admissions in 12 cities is an innovation in Europe. The evidence arising from the project's results, namely the literature review, the investigation of the stateof-the-art in the participating cities (feasibility), and the identification of susceptible populations (target groups), offer an important contribution for guidelines for preventive strategies and health care actions taken to lessen morbidity and mortality effects. The results of this project contribute to policy development, public health decisionmaking, and will be an important input for cost-benefit analysis and risk communication.

\section{Competing interests}

The author(s) declare that they have no competing interests.

\section{Authors' contributions}

PM coordinated the project, supervised hospital admissions analysis and participated in all methodological discussions. UK coordinated the data collection, dealt with administrative and financial issues, organized the meetings and contributed to the writing of the present paper. KK was the leader of the Epidemiology and Statistics working group, shared the methodological decisions with $\mathrm{PM}$ and $\mathrm{AB}$, supervised the analysis on winter mortality and was responsible for the investigation of air pollutants as potential confounders or effect modifiers. $A B$ shared the development of the methodology with PM and KK and supervised summer mortality analysis. GMG was responsible for the development of HHWWS in five cities 
and was the leader of the Meteorology working group. BM was responsible for all public health related issues and the organisation of the final work shop. PK carried out the analysis of meteorological indicators for all cities. HRA was the leader of the Public Health working group. MB and AA participated in the methodological discussion and carried out mortality analysis for summer and winter, respectively. GA contributed to the methodological discussion and carried out hospital admission analysis. TK performed health impact assessment of heat on mortality in collaboration with $\mathrm{AB}$ and $\mathrm{MB}$ and developed and implemented the city specific questionnaire for the assessment of prevention programmes in place. All authors read and approved the final manuscript.

\section{Acknowledgements}

The dataset used in the present project was compiled by health, meteorological and air pollution data from 16 European cities, provided by the following institutions and participants (PHEWE collaborative group):

Department of Epidemiology, Local Health Authority RM/E, Rome, Italy: P Michelozzi, U Kirchmayer, G Accetta, F de'Donato, M D'Ovidio, D D'lppoliti, C Marino, M Becker; School of Geography and Environmental Sciences, University of Birmingham, Birmingham, UK: G McGregor; Department of Statistics, University of Florence, Florence, Italy: A Biggeri, M Baccini; WHO - Regional Office for Europe, Rome, Italy: B Menne, T Kosatsky; Department of Hygiene \& Epidemiology, University of Athens Medical School, Athens, Greece: K Katsouyanni, A Analitis; Department of Astrogeophysics, University of Joannina, Joannina, Greece: P Kassomenos; Municipal Medical Research Institute, Barcelona, Spain: J Sunyer; Division of Community Health Sciences, St. George's, University of London, UK: HR Anderson, R Atkinson; National Institute for Public Health Surveillance, Saint Maurice, France: S Medina; National Centre of Public Health, Institute of Environmental Health, Budapest, Hungary: A Paldy; Department of Epidemiology, Health Authority Milan, Milan, Italy: L Bisanti; Regional Environmental Protection Agency of Piedmont, Grugliasco, Italy: E Cadum; Department of Epidemiology, Charles University, Prague, Czech Republic: B Kriz; Department of Environmental Health, Institute of Public Health, Ljubljana, Slovenia: A Hojs; St. James's Hospital, Dublin, Ireland: L Clancy, P Goodman; Department of Environmental Health, Umea University, Sweden: B Forsberg; Unit of Environmental Epidemiology, National Public Health Institute, Kuopio, Finland: J Pekkanen; Department of Medical Statistics, National Institute of Hygiene, Warsaw, Poland: B Woityniak; Department of Mathematical Sciences, University of Aberdeen, UK: I jolliffe; German Meteorology Service, Freiburg, Germany: G Jendritzky; Department of Climatology, Institute of Geography and Spatial Organization, Warszawa, Poland: K Blazejczyk; Institute of Atmospheric Physics, Academy of Sciences, Prague, Czech Republic: R Huth; Climatological Department, Meteorological Office, Environmental Agency, Ljubljana, Slovenia: T Cegnar; Institute of Social and Preventive Medicine, University of Basel, Switzerland: C. Schindler; Valencia School of Health Studies, Valencia, Spain: F Ballester; French Meteorology Service, Roissy Charles De Gaulle, France: G Monceau; Centre for Climatic Research, University of Delaware, USA: LS Kalkstein.

Funding: the PHEWE project is funded by the European Commission, Directorate General Research.

\section{References}

I. McMichael AJ: Global environmental change and human population health: a conceptual and scientific challenge for epidemiology. Int J Epidemiol 1993, 22: I-8.

2. Meehl GA, Zwiers F, Evans J, Knutson T, Mearns L, Whetton P. Trends in extreme weather and climate events: issues related to modelling extreme in projections of future climate change. Bull Amer Meteor Soc 2000, 8 I:427-36.

3. WHO/WMO/UNEP: Climate and health: The potential impacts of climate change Geneva, Swizterland; 1996.

4. Basu R, Samet J: Relation between elevated ambient temperature and mortality: a review of the epidemiologic evidence. Epidemiol Rev 2002, 24:190-202.

5. Curriero FC, Heiner KS, Samet JM, Zeger SL, Strug L, Patz JA: Temperature and mortality in II cities of the Eastern United States. Am J Epidemiol 2002, I 55:80-87.

6. Keatinge W, Donaldson G: Mortality related to cold and air pollution in London after allowance for effects of associated weather patterns. Environ Res 2001, 86:209-216.

7. Eurowinter Group: Cold exposure and winter mortality from ischaemic heart disease, cerebrovascular disease, respiratory disease, and all causes in warm and cold regions of Europe. Lancet 1997, 349:134 I-1346.

8. Kovats RS, Hajat S, Wilkinson P: Contrasting patterns of mortality and hospital admissions during hot weather and heat waves in Greater London, UK. Occup Environ Med 2004, 6 I:893-898.

9. Schwartz J, Samet JM, Patz JA: Hospital admissions for heart disease: the effects of temperature and humidity. Epidemiology 2004, I 5:755-76I.

10. Kunst AE, Looman C, Mackenbach J: Outdoor air temperature and mortality in the Netherlands: a time-series analysis. Am J Epidemiol 1993, 137:331-341.

II. Alberdi JC, Diaz J, Montero JC, Miron I: Daily mortality in Madrid community 1986-1992: relationship with meteorological variables. Eur J Epidemiol 1998, 14:57 I-578.

12. Ballester F, Corella D, Perez-Hoyos S, Saez M, Hervas A: Mortality as a function of temperature. A Study in Valencia, Spain, | 99 |-1993. Int J Epidemiol 1997, 26:55|-56|.

13. Braga ALF, Zanobetti A, Schwartz J: The effect of weather on respiratory and cardiovascular deaths in 12 U.S. cities. Environ Health Perspect 2002, I I 0:859-863.

14. Keatinge WR, Coleshaw SR, Cotter F, Mattock M, Murphy M, Chelliah R: Increased platelet and red cell counts, blood viscosity, and arterial pressure during mild surface cooling: factors in mortality from coronary and cerebral thrombosis in winter. BMJ 1984, 289: I405-1408.

15. Katsouyanni K, Schwartz J, Spix C, Touloumi G, Zmirou D, Zanobetti A, Wojtyniak B, Vonk JM, Tobias A, Ponka A, Medina S, Bacharova L, Anderson HR: Short term effects of air pollution on health: a European approach using epidemiologic time series data: the APHEA protocol. J Epidemiol Community Health 1996:SI2-18.

16. Katsouyanni K, Touloumi G, Spix C, Schwartz J, Balducci F, Medina S, Rossi G, Wojtyniak B, Sunyer J, Bacharova L, Schouten JP, Ponka A, Anderson HR: Short term effect of ambient sulphur dioxide and particulate matter on mortality in 12 cities: results from time series data from the APHEA project. Air Pollution and Health: a European Approach. BMJ 1997, 3 | 4:1658-1663.

17. Rooney C, McMichael AJ, Kovats RS, Coleman MP: Excess mortality in England and Wales. And in Greater London, during the I995 heatwave. J Epidemiol Community Health I998, 52:482-486.

18. Keatinge WR, Coleshaw SR, Easton JC, Cotter F, Mattock MB, Chelliah R: Increased platelet and red cell counts, blood viscosity, and plasma cholesterol levels during heat stress, and mortality from coronary and cerebral thrombosis. Am J Med I986, $81: 795-800$

19. Kilbourne EM: The spectrum of illness during heat waves. Am J Prev Med 1999, 6:359-360.

20. Michelozzi P, de' Donato F, Accetta G, Forastiere F, D'Ovidio M, Perucci CA: Impact of heat waves on mortality - Rome, Italy, June-August 2003. JAMA 2004, 291:2537-2538.

21. Schwartz J: Who is sensitive to extremes of temperature? A case-only analysis. Epidemiology 2005, 16:67-72.

22. Saez M, Sunyer J, Castellsagué J, Murillo C, Antó JM: Relationship between weather temperature and mortality: a time series analysis approach in Barcelona. Int J Epidemiol 1995, 24:576-582. 
23. Steadman RG: The assessment of sultriness: Part I: A temper ature-humidity index based on human physiology and clothing science. J Appl Meteorol 1979, I 8:861-873.

24. Kalkstein LS, Valimont KM: An evaluation of summer discomfort in the United States using a relative climatological index. Bull Am Meteor Soc 1986, 67:842-848.

25. O'Neill MS, Zanobetti A, Schwartz J: Modifiers of the temperature and mortality association in seven US cities. Am J Epidemiol 2003, I 57: 1074-1082.

26. Liang $\mathrm{KY}$, Zeger SL: Longitudinal analysis using generalized linear models. Biometrika |986, 73:13-22.

27. Chiogna M, Gaetan CG: Transfer function modelling strategy for combining evidence on air pollution and daily mortality. In Proceedings of the Conference S.Co.2003: 4-6 September 2003; Treviso Edited by: Mantovan P, et al. Venezia: Department of Statistics: 2003:| $40-145$

28. Chiogna $M$, Gaetan CG: Mining epidemiological time series: an approach based on dynamic regression. Statistical Modelling 2005, 5:309-325

29. Touloumi G, Samoli E, Quenel P, Paldy A, Anderson RH, Zmirou D, Galan I, Forsberg B, Schindler C, Schwartz J, Katsouyanni K: Shortterm effects of air pollution on total and cardiovascular mortality: the confounding effect of influenza epidemics. Epidemiology 2005, I:49-57.

30. Muggeo VM: Estimating regression models with unknown break-points. Stat Med 2003, 22:3055-307I.

31. Samoli E, Touloumi G, Zanobetti A, Le Tertre A, Schindler C, Atkinson R, Vonk J, Rossi G, Saez M, Rabczenko D, Schwartz J, Katsouyann $\mathrm{K}$ : Investigating the dose-response relation between air pollution and total mortality in the APHEA-2 multicity project. Occup Environ Med 2003, 60:977-982.

32. Diaz J, Garcia R, Velazquez de Castro F, Hernandez E, Lopez C, Otero A: Effects of extremely hot days on people older than 65 years in Seville (Spain) from 1986 to 1997. Int J Biometeorol 2002, 46: | $45-149$.

33. Keatinge WR, Donaldson GC, Cordioli E, Martinelli M, Kunst AE, Mackenbach JP, Näyhä S, Vuori I: Heat related mortality in warm and cold regions of Europe: observational study. BM] 2000, $321: 670-673$.

34. Hajat S, Kovats RS, Atkinson RW, Haines A: Impact of hot temperatures on death in London: a time series approach. J Epidemiol Community Health 2002, 56:367-372.

35. Michelozzi P, Fano V, Forastiere F, Barca A, Kalkstein LS, Perucci CA: Weather conditions and elderly mortality in Rome during summer. WMO Bulletin 2000, 49:348-355.

36. Semenza JC, McCullough JE, Flanders WD, McGeehin MA, Lumpkin JR: Excess hospital admissions during the July 1995 heat wave in Chicago. Am J Prev Med 1999, 16:269-277.

37. Kalkstein LS, Davis RE: The development of a weather/mortality model for environmental impact assessment. In Proceedings of the 7th Conference of Biometeorology and Aerobiology: 2 I-24 May 1985; Scottsdale, AZ Edited by: . American Meteorological Society. Boston, MA; 1985:334-336.

38. Kalkstein LS, Jamason PF, Greene JS, Libby J, Robinson L: The Philadelphia Hot Weather-Health Watch/Warning System: development and application, summer 1995. Bull Am Meteor Soc 1996, 77:1519-1528.

39. Kalkstein LS: A new approach to evaluate the impact of climate on human mortality. Environ Health Perspect 1991, 96: $145-150$.

40. Scharlau K: Einfuhrung eines Schwulemasstabes und Abgrenzung von Schwulezonen durch Isohygrothermen. Erdkunde 1950, 4:188-201.

4I. Thom EC, Bosen JF: The discomfort index. Weatherwise 1959 I 2:57-60.

42. Kyle W]: The human bioclimate of Hong Kong. In Proceedings of the Contemporary Climatology Conference: 15-20 August 1994; Brno, Czech Republic Edited by: Brazdil R, Kolář M. Tisk Litera, Brno; 1994:345-350.

43. Pepi WJ, Maynard MA: The New Summer Simmer Index: comfort index for the new millenium. In International audience at the 80th annual meeting of the AMS: I I January 2000; Long Beach, California American Meteorological Society. Boston, MA; 2000.

44. Smoyer RG, Rainham DG, Hewko JN: Heat-stress-related mortality in five cities in Southern Ontario: 1980-1996. Int J Biometeorol 2000, 44:190-197.
45. O'Neill MS, Hajat S, Zanobetti A, Ramirez-Aguilar M, Schwartz J: Impact of control for air pollution and respiratory epidemics on the estimated associations of temperature and daily mortality. Int J Biometeorol 2005, 50: | 21- | 29.

46. Choi GY, Choi JN, Kwon HJ: The impact of high apparent temperature on the increase of Summertime Disease-related mortality in Seoul: |99|-2000. I Prev Med Pub Health 2005, 38:283-290.

47. Stafoggia M, Forastiere F, Agostini D, Biggeri A, Bisanti L, Cadum E, Caranci N, de' Donato F, De Lisio S, De Maria M, Michelozzi P, Miglio R, Pandolfi P, Picciotto S, Rognoni M, Russo A, Scarnato C, Perucci CA: Vulnerability to heat-related mortality: a multicity, populationbased, case-crossover analysis. Epidemiology 2006, I7:315-323.

48. Michelozzi P, De Sario M, Accetta G, de' Donato F, Kirchmayer U D'Ovidio M, Perucci CA, HHWWS Collaborative Group: Temperature and summer mortality: geographical and temporal variations in four Italian cities. I Epidemiol Community Health 2006, 60:417-423.

49. Schwartz J: Air pollution and daily mortality: a review and meta-analysis. Environ Res 1994, 64:36-52.

50. Schwartz J: Non-parametric smoothing in the analysis of air pollution and respiratory illness. Can J Stat 1994, 22:47|-487.

5I. Hajat S, Armstrong BG, Gouveia N, Wilkinson P: Mortality displacement of heat-related deaths. A comparison of Delhi, Sao Paulo, and London. Epidemiology 2005, I 6:6 13-620.

52. Rotton J: Angry, sad, happy? Blame the weather. US News World Rep 1983, 95:52-53.

53. Ellis FP: Mortality from heat illness and heat-aggravated illness in the United States. Environ Res 1972, I 5:504-5 I 2.

54. Katsouyanni K, Pantazopoulou A, Touloumi G, Tselepidaki I, Moustris K, Asimakopoulos D, Poulopoulou G, Trichopoulos D: Evidence for interaction between air pollution and high temperature in the causation of excess mortality. Arch Environ Health 1993. 48:235-242.

55. Samet J, Zeger S, Kelsall J, Xu J, Kalkstein L: Does weather confound or modify the association of particulate air pollution with mortality? An analysis of the Philadelphia data, 19731980. Environ Res 1998, 77:9-19.

Publish with Biomed Central and every scientist can read your work free of charge

"BioMed Central will be the most significant development for disseminating the results of biomedical research in our lifetime. "

Sir Paul Nurse, Cancer Research UK

Your research papers will be:

- available free of charge to the entire biomedical community

- peer reviewed and published immediately upon acceptance

- cited in PubMed and archived on PubMed Central

- yours - you keep the copyright
BiolMedcentral 